\title{
FAKTOR-FAKTOR PENYEBAB KEJADIAN \\ PREEKLAMSIA/EKLAMSIA PADA IBU BERSALIN \\ DI RUANG BERSALIN RUMAH SAKIT UMUM DAERAH \\ PANEMBAHAN SENOPATI BANTUL
}

\author{
Agnes Mahayanti ${ }^{1}$, Ngatini $^{2}$ \\ ${ }^{1}$ STIKes Panti Rapih Yogyakarta, Jl. Tantular No 401, Condongcatur, Depok, \\ Sleman, Yogyakarta, email: agnes_mahayanti@stikespantirapih.ac.id \\ ${ }^{2}$ STIKes Panti Rapih Yogyakarta, Jl. Tantular No 401, Condongcatur, Depok, \\ Sleman, Yogyakarta, email: agnes_mahayanti@stikespantirapih.ac.id
}

\begin{abstract}
ABSTRAK
Latar Belakang: Preeklamsi merupakan penyebab kematian ibu nomer dua di Indonesia yang ditandai dengan peningkatan tekanan darah, protein urine positif dan oedema.

Tujuan: Penelitian bertujuan untuk mengetahui faktor-faktor penyebab kejadian preeklampsia/eklamsia pada ibu bersalin diruang bersalin RSUD Panembahan Senopati Bantul.

Metode: Penelitian menggunakan desain cross sectional. Subyek penelitian adalah $86 \mathrm{ibu}$ bersalin dari bulan Januari-Juni 2019. Teknik analisis data menggunakan analisis univariat dengan distribusi frekuensi, analisis bivariat dengan chi-square dan analisis multivariat digunakan untuk mengetahui Model Fiiting Information, Pseudo R-Square dan parameter estimate faktor-faktor penyebab terjadinya preklamsia/eklamsia.

Hasil: Sebanyak 58,1\% responden mengalami kejadian preeklamsia/eklamsia ringan, 41,9\% merupakan preeklamsi/eklamsia sedang. Hasil analisis chi-square nilai $p$ value $<0,05$ terdapat pada variabel penyakit kronis, umur ibu, $\mathrm{KB}$, ANC dan pendidikan ibu. Nilai statistik chi-square sebesar 2466,177 (Pearson) $(>90,00)$ dengan nilai signifikansi $0,000(<0,000)$. variabel independent penyakit kronis, umur ibu, KB, ANC dan pendidikan ibu memberikan kontribusi terhadap kejadian preeklamsia/eklamsia sebesar $62,2 \%$.
\end{abstract}

Simpulan: Faktor penyebab kejadian preeklamsia/eklamsia pada ibu bersalin di RSUD Panembahan Senopati meliputi penyakit kronis, perilaku pemeriksanaan ANC dan umur ibu dengan nilai $p$-value 0,000 , Keluarga Berencana dengan nilai $p$ value 0,013 , pendidikan ibu dengan nilai $p$ value 0,013 . Variabel riwayat 
Faktor-Faktor Penyebab Kejadian Preeklamsia/Eklamsia Pada Ibu Bersalin Di

Ruang Bersalin Rumah Sakit Umum Daerah Panembahan Senopati Bantul

komplikasi, paritas tidak memberikan pengaruh secara signifikan terhadap kejadian preeklamsia/eklamsia pada ibu bersalin. Saran dari hasil penelitian ini adalah ibu hamil dengan salah satu faktor ataupun lebih dapat lebih diperhatikan oleh tenaga kesehatan sehingga tidak terjadi komplikasi yang tidak diharapkan.

Kata Kunci: Faktor penyebab, preeklamsia-eklamsia

\begin{abstract}
Background: Preeclampsia / eclampsia is the second leading cause of maternal death in Indonesia, which be marked by increasing blood pressure, positive urine protein and edema.

Objective: The purposes of this study to determine the factors that causing the incidence of preeclampsia / eclampsia in delivery Room Of Panembahan Senopati Hospital Bantul.

Methods: This study used a cross sectional design. The research subjects were 86 mothers giving birth from January-June 2019. The data analysis technique used univariate analysis with frequency distribution, bivariate analysis with chi-square and multivariate analysis was used to determine the Fiiting Information Model, Pseudo R-Square and parameter estimates of causal factors. the occurrence of preeclampsia / eclampsia.
\end{abstract}

Results: $58.1 \%$ of respondents had preeclampsia / mild eclampsia, $41.9 \%$ were moderate preeclampsia / eclampsia. The results of the $\mathrm{C}$-square analysis $p$ value $<0.05$ was found in the variables of chronic disease, maternal age, family planning, ANC and maternal education. The Chi-Square statistical value is 2466.177 (Pearson) $(>90.00)$ with a significance value of $0.000(<0.000)$. The independent variables of chronic disease, maternal age, family planning, ANC and maternal education contributed $62.2 \%$ to the incidence of preeclampsia / eclampsia.

Conclusion: Factors that causing the incidence of preeclampsia / eclampsia in delivery room at Panembahan Senopati Hospital include chronic disease with a $\mathrm{p}$ value of 0,000 , maternal age with a $p$ value of 0,000 , ANC examination behavior with $p$ value of 0.00 , family planning with $p$ value of 0.013 , maternal education with a $p$ value of 0.013 . Variables history of complications, parity did not have a significant effect on the incidence of preeclampsia/eclampsia in women who gave birth. The suggestion of this research is that pregnant women with one or more factors can be given more by health worker so that there are no unexpected complication.

Keywords: Causative factors, Preeclampsia-Eclamps 


\section{PENDAHULUAN}

Angka Kematian Ibu (AKI) di Indonesia masih menjadi salah satu masalah kesehatan krusial pada ibu dan anak. Pada tahun 2018 angka kematian ibu (AKI) masih berkisar 305 per kelahiran hidup. Di Kabupaten Bantul, Angka Kematian Ibu tahun 2018 mengalami penurunan dibandingkan 2017. Hal ini ditandai dengan turunnya angka kematian ibu, jika pada tahun 2018 sebesar 108,36/100.000 Kelahiran Hidup sejumlah 14 kasus, sedangkan pada Angka Kematian Ibu Tahun 2017 sebesar 72,85/100.000 Kelahiran Hidup yaitu sejumlah 9 kasus. Berdasarkan hasil Audit Maternal Perinatal (AMP) didapatkan data bahwa penyebab kematian ibu pada tahun 2018 adalah Pre Eklampsi Berat (PEB) sebanyak $11 \%$ (1 kasus), perdarahan sebanyak 17\% (2 kasus), dan sepsis, hipertiroid, paripartum, infeksi paru dan lainnya 11\% (1 kasus)

(Dinas Kesehatan Kabupaten Bantul, 2019). terutama primigravida muda, frekuensi preeklampsia meningkat dibandingkan pada multigravida (Depkes, 2012).Berdasarkan data
Deteksi dan penatalaksanaan dini pada ibu yang memiliki risiko preeklamsi menjadi faktor penting dalam penatalaksanaan preeklampsi / eklamsia. Ibu harus mendapatkan tindak lanjut secara teratur dan diberikan instruksi yang jelas kapan harus kembali ke pelayanan kesehatan. Penyuluhan ke anggota keluarga juga sangat penting untuk meningkatkan dukungan sosial jika dibutuhkan hospitalisasi dan perubahan aktivitas kerja (Prawirohardjo, 2009).

Angka kejadian Preeklamsi cenderung lebih banyak terjadi di negara berkembang daripada di negara maju. Kejadian preeklampsia dapat dipengaruhi oleh umur, hipertensi sebelumya, faktor genetik, dan lingkungan. Kehamilan dengan preeklampsi lebih banyak terjadi pada primigravida. Preeklamsi pada multigravida lebih banyak berhubungan dengan penyakit hipertensi kronis, diabetes militus, dan penyakit ginjal. Pada primigravida studi pendahuluan dari RSUD Panembahan Senopati Bantultahun 2018 mendapatkan hasil bahwa ada 86 kasus preeklampsia / eklampsia dari 15 
Faktor-Faktor Penyebab Kejadian Preeklamsia/Eklamsia Pada Ibu Bersalin Di Ruang Bersalin Rumah Sakit Umum Daerah Panembahan Senopati Bantul

2834 kasus persalinan di RSUD Panembahan Senopati Bantul. Penelitian ini bertujuan untuk mengetahui faktor penyebab kejadian preeklampsia pada ibu bersalin di RSUD Panembahan Senopati Bantul tahun 2019.

\section{METODOLOGI PENELITIAN}

Penelitian ini adalah penelitian kuantitatif study case control design dengan pendekatan retrospektif. Penelitian dilakukan di RSUD Panembahan Senopati Bantul pada tanggal 9 Agustus 2019. Responden penelitian adalah rekam medis ibu bersalin antara bulan Januari-Juni 2019 sebanyak 86 rekam medis. Kriteria responden yang diambil adalah ibu melahirkan dengan preeklampsi dan eklampsia sejak Januari -Juni 2019 dan data rekam medis terisi lengkap. Kriteria ekslusi dalam penelitian ini adalah bu memiliki penyakit ginjal, hati, autoimun, HIV. Teknik sampling yang digunakan adalah total populasi. Data berasal dari rekam medis pasien selanjutnya dimasukkan dalam master table dan diolah menggunakan program computer. Analisa data dilakukan dengan univariat, bivariat dengan uji statistik chi-square test dan multivariat analisis multivariat digunakan untuk mengetahui Model Fiiting Information, Pseudo R-Square dan parameter estimate faktor-faktor penyebab terjadinya preklamsia/eklamsia

\section{HASIL DAN PEMBAHASAN}

Hasil analisis karakteristik responden yang terdiri dari agama, umur kehamilan, pekerjaan, penyakit kronis, riwayat komplikasi, usia, paritas, KB, ANC, pendidikan ibu dapat dilihat pada tabel berikut 
Tabel 1.

Distribusi Frekuensi Karakteristik Responden Di Rumah Sakit Umum Daerah Panembahan Senopati Bantul Pada Bulan Juli 2019

\begin{tabular}{|c|c|c|}
\hline KARAKTERISTIK & JUMLAH & $\%$ \\
\hline \multicolumn{3}{|l|}{ Agama } \\
\hline Katolik & 2 & 2,3 \\
\hline Islam & 84 & 97,7 \\
\hline JUMLAH & 86 & 100,0 \\
\hline \multicolumn{3}{|l|}{ Umur Kehamilan } \\
\hline$<37$ atau $>42$ & 19 & 22,1 \\
\hline $37-42$ & 67 & 77,9 \\
\hline JUMLAH & 86 & 100,0 \\
\hline \multicolumn{3}{|l|}{ Pekerjaan } \\
\hline Buruh & 10 & 11,6 \\
\hline Swasta & 15 & 17,4 \\
\hline Petani & 1 & 1,2 \\
\hline Pedagang & 2 & 2,3 \\
\hline IRT & 56 & 65,1 \\
\hline Guru & 1 & 1,2 \\
\hline JUMLAH & 86 & 100,0 \\
\hline \multicolumn{3}{|l|}{ Penyakit Kronis } \\
\hline Ya (ada penyakit kronis) & 21 & 24,4 \\
\hline Tidak (Tidak ada penyakit kronis) & 65 & 75,6 \\
\hline JUMLAH & 86 & 100,0 \\
\hline \multicolumn{3}{|l|}{ Riwayat Komplikasi } \\
\hline Ya (Ada Riwayat Komplikasi) & 4 & 4,7 \\
\hline Tidak (Tidak ada riwayat komplikasi) & 82 & 95,3 \\
\hline JUMLAH & 86 & 100,0 \\
\hline \multicolumn{3}{|l|}{ Umur Ibu } \\
\hline$<20$ atau $>35$ (Umur Ibu beresiko) & 36 & 41,9 \\
\hline 20-35 (Umur ibu tidak beresiko) & 50 & 58,1 \\
\hline JUMLAH & 86 & 100,0 \\
\hline \multicolumn{3}{|l|}{ Paritas } \\
\hline$<2$ atau $>4$ (aritas beresiko) & 33 & 38,4 \\
\hline 2-4 (Paritas tidak beresiko) & 53 & 61,6 \\
\hline JUMLAH & 86 & 100 \\
\hline \multicolumn{3}{|l|}{ KB } \\
\hline Ya (Jika ibu menggunakan alat KB) & 39 & 45,3 \\
\hline Tidak (Jika ibu tidak menggunakan alat KB) & 47 & 54,7 \\
\hline JUMLAH & 86 & 100 \\
\hline
\end{tabular}


Agnes Mahayanti, Ngatini

Faktor-Faktor Penyebab Kejadian Preeklamsia/Eklamsia Pada Ibu Bersalin Di Ruang Bersalin Rumah Sakit Umum Daerah Panembahan Senopati Bantul

\begin{tabular}{lcc}
\hline KARAKTERISTIK & JUMLAH & \% \\
\hline ANC & & \\
Tidak ANC & 6 & 7,0 \\
ANC sesuai standar minimal/lebih & 60 & 69,8 \\
\hline JUMLAH & $\mathbf{8 6}$ & $\mathbf{1 0 0}$ \\
\hline Pendidikan Ibu & & \\
Tidak sekolah, SD,SMP & 50 & 58,1 \\
SMA, PT & 53 & 61,6 \\
\hline JUMLAH & $\mathbf{8 6}$ & $\mathbf{1 0 0 , 0}$ \\
\hline Sumber: Data sekunder diolah peneliti, 2019 & &
\end{tabular}

Sebagian besar responden beragama islam, sebagai ibu rumah tangga, dengan umur kehamilan pada 37-42 minggu. Sebagian besar responden tidak ada penyakit kronis, tidak ada riwayat komplikasi, ibu berusia 20-35 tahun dengan paritas gravida 2 sampai dengan gravida 4 , tidak menggunakan alat $\mathrm{KB}$, melakukan pemeriksaan ANC sesuai dengan standar trimeter I satu kali, Trimester II satu kali, trimester III 2 kali dan ibu yang berpendidikan tinggi (SMA, PT) memiliki sebaran sama baik dengan yang berpendidikan rendah (Tidak sekolah, SD,SMP)
Tabel 2

Distribusi Frekuensi Responden ierdasarkan kejadian preeklamsi/eklamsia di RSUD Panembahan Senopati Bantul

\begin{tabular}{ccc}
\multicolumn{3}{c}{ Bulan Januari-Juni 2019} \\
\hline KEJAD & JUML & \% \\
IAN & AH & \\
PEB & & 58,1 \\
\hline Ringan & 50 & 41,9 \\
Sedang & 36 & 0 \\
Berat & 0 & 100,0 \\
Jumlah & 86 & Sumber: Data sekunder diolah peneliti, 2019
\end{tabular}

Angka kejadian PEB persentase terbesar terdapat pada PEB ringan $(58,1 \%)$. 
Tabel 3

Faktor-Faktor Penyebab Kejadian Preeklamsia/eklamsia di Ruang Bersalin RSUD Panembahan

Senopati Bantul Bulan Januari-Juni 2019

\begin{tabular}{lc}
\hline Faktor Penyebab & $\begin{array}{c}\text { Nilai } \boldsymbol{p} \text { value } \\
\text { Chi Square }\end{array}$ \\
\hline Penyakit Kronis & $\mathbf{0 , 0 0 0}$ \\
Riwayat Komplikasi & 0,484 \\
Umur Ibu & $\mathbf{0 , 0 0 0}$ \\
Paritas & 0,594 \\
KB & $\mathbf{0 , 0 3 3}$ \\
ANC & $\mathbf{0 , 0 0 1}$ \\
Pendidikan ibu & $\mathbf{0 , 0 0 0}$ \\
\hline
\end{tabular}

Sumber : Data Sekunder di Olah Peneliti, 2019

Data hubungan variabel independen terhadap dependen dapat dilihat pada nilai $p$ value $<0,05$, terdapat pada variabel penyakit kronis, umur ibu, KB, ANC dan pendidikan ibu. Secara statistik disimpulkan bahwa variabel status kesehatan meliputi penyakit kronis, status reproduksi meliputi umur ibu, Perilaku pemeriksanaan antenatal care (ANC) dan penggunaan keluarga berencana (KB), dan karakteristik responden meliputi pendidikan ibu memberikan pengaruh secara signifikan terhadap kejadian preeklamasia/eklamsia pada ibi bersalin. Sementara variabel status kesehatan meliouti riwayat komplikasi dan status reproduksi meliputi paritas tidak memberikan pengaruh secara signifikan terhadap kejadian preeklamasia/eklamsia pada ibu bersalin.

Tabel 4

\begin{tabular}{ccccc}
\multicolumn{5}{c}{ Model Fiiting Information } \\
\hline Model & -2 Log & Chi & df & Sig. \\
& Likehood & Square \\
\hline Intercept & 113,349 \\
Only & & 83,554 & 8 & .000 \\
Final & 29,794 & & & \\
\hline
\end{tabular}

Sumber: Data sekunder diolah peneliti, 2019

Dari tabel 4 didapatkan data bahwa nilai nilai $-2 \mathrm{LL}$ awal sebesar 113,349 sedangkan nilai -2 LL pada model final sebsar 29,794. Nilai tersebut terjadi oenurunan nilai $-2 \log$ Likehood sebesar 83,554 dan signifikan pada 0,000 .

Tabel 5

Goodnest Of Fit Tes

\begin{tabular}{lccc}
\hline & Chi Square & df & Sig. \\
\hline Pearson & 2466,177 & 28 & .000 \\
Deviance & 27,971 & 28 & .466
\end{tabular}

Sumber: Data sekunder diolah peneliti, 2019 
Agnes Mahayanti, Ngatini

Faktor-Faktor Penyebab Kejadian Preeklamsia/Eklamsia Pada Ibu Bersalin Di Ruang Bersalin Rumah Sakit Umum Daerah Panembahan Senopati Bantul

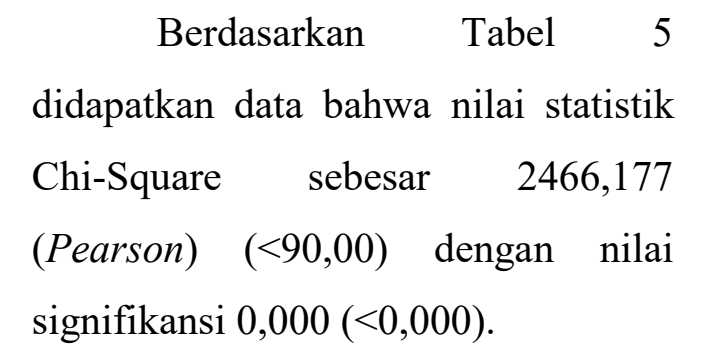

Tabel 6

Pseudo R-Square

\begin{tabular}{ll}
\hline Cox and Snell &, 622 \\
Nagelkerge &, 836 \\
McFadden &, 715 \\
\hline
\end{tabular}

Sumber: Data sekunder diolah peneliti, 2019

Berdasarkan tabel 6 di dapatkan data bahwa nilai cox amd Snell 0,622. Secara statistik disimpulkan bahwa variabel independent penyakit kronis, umur ibu, KB, ANC dan pendidikan ibu memberikan kontribusi terhadap kejadian preeklamsia/eklamsia sebesar $\quad 62,2 \%$. Sejumlah 37,8\% dijelaskan oleh variabel di luar model/variabel yang tidak di teliti.

Tabel 7 Parameter Estimates

\begin{tabular}{rc}
\hline Karakteristik & $\begin{array}{c}\text { Nilai } \boldsymbol{p} \\
\text { value } \\
\text { regresi }\end{array}$ \\
Penyakit Kronis & $\mathbf{0 , 0 0 1}$ \\
Riwayat Komplikasi & 0,927
\end{tabular}

\begin{tabular}{ll} 
Umur Ibu & $\mathbf{0 , 0 0 1}$ \\
Paritas & 0,594 \\
KB & $\mathbf{0 , 0 3 7}$ \\
ANC & $\mathbf{0 , 0 0 3}$ \\
\multicolumn{1}{c}{ Pendidikan ibu } & $\mathbf{0 , 0 0 3}$
\end{tabular}

Sumber: Data sekunder diolah peneliti, 2019 Secara statistik disimpulkan bahwa variabel status kesehatan meliputi penyakit kronis, status reproduksi meliputi umur ibu dan paritas, Perilaku pemeriksanaan antenatal care (ANC) dan penggunaan keluarga berencana (KB), dan karakteristik responden meliputi pendidikan ibu penyakit kronis, umur ibu dan paritas, KB, ANC dan pendidikan ibu memberikan pengaruh secara signifikan terhadap kejadian PEB. Sementara variabel riwayat komplikasi dan paritas tidak memberikan pengaruh secara signifikan terhadap kejadian preeklamsia/eklamsia.

Preeklamsia adalah kondisi peningkatan tekanan darah yang muncul setelah usia kehamilan 20 minggu, kondisi ini dapat disertai dengan penambahan berat badan ibu yang cepat akibat odema dan hasil pemeriksaan urine ada proteinuri 20 
positif (Fatmawati, et. al., 2017). pada kehamilan sebelumnya Sindroma preeklamsia ringan seperti berhubungan secara signifikan dengan hipertensi, oedema, dan proteinuria kejadiaan preeklampsia. Penelitian lain sering tidak diperhatikan sehingga tanpa disadari dalam waktu singkat dapat timbul preeklamsia berat, bahkan eklamsia (Prawirohardjo, 2009).

Hal ini menunjukkan bahwa ibu bersalin yang mempunyai riwayat penyakit kronis dapat berisiko mengalami preeklamsia. Hasil penelitian ini sesuai dengan hasil penelitian yang dilakukan Fadlun (2012), preeklampsia pada hipertensi kronik yaitu preeklampsia yang terjadi pada perempuan hamil yang telah menderita hipertensi sebelum hamil. Penyakit kronis yang lain seperti diabetes, penyakit ginjal, dan obesitas juga dapat menyebabkan preeklampsia. Hasil penelitian sama dengan penelitian Wahyuni,dkk (2015) tentang "Faktor-faktor yang Berhubungan dengan Kejadian Preeklampsia pada Ibu Hamil di Rumah Sakit Roemani Muhammadiyah Semarang", dengan hasil ada riwayat penyakit yang lalu seperti hipertensi, riwayat preeklamsi yang mempunyai hasil sama adalah penelitian Apri, dkk (2012) tentang "Faktor - Faktor yang Berhubungan Dengan Terjadinya Preeklampsia Eklampsia di RSUD Raden Mattaher Jambi " ( $p$ value $=0.000)$. Faktor risiko terbesar terjadi preeklamsia 8,4 kali adalah riwayat preeklamsia sebelumnya, riwayat hipertensi $5,1 \%$ menyebabkan terjadi preeklamsia, dan $3,7 \%$ pregestational diabetes menjadi risiko terjadi preeklamsia. Sebuah meta analisis terbaru mengevaluasi hubungan antara preeklampsia dan 14 faktor klinis yang dapat dinilai pada atau sebelum 16 minggu kehamilan seperti riwayat preeklampsia, solutio plasenta sebelumnya, IUGR sebelumnya, bayi lahir mati (stillbirth), nulipara, usia ibu hamil lebih dari 35 dan lebih dari 40, overweight (BMI di atas $25 \mathrm{~kg} / \mathrm{m} 2$ ) atau obesitas (BMI di atas $30 \mathrm{~kg} / \mathrm{m} 2$ ), hipertensi kronis, diabetes melitus (tipe 1 atau tipe 2), penyakit ginjal kronis, SLE, sindrom antibodi antiphospholipid, dan kehamilan multifetal. Meskipun 
Faktor-Faktor Penyebab Kejadian Preeklamsia/Eklamsia Pada Ibu Bersalin Di Ruang Bersalin Rumah Sakit Umum Daerah Panembahan Senopati Bantul

kondisi ini tidak dapat memprediksi preeklampsia namun informasi yang terkait dengan faktor-faktor risiko ini penting dikaji oleh tenaga kesehatan pada saat kunjungan ANC pertama. Informasi ini dapat membantu tenaga kesehatan mengidentifikasi siapa saja yang berisiko terkena preeklamsia yang mungkin berisiko tinggi preeklampsia (Anderson \& Schmella, 2017).

Berdasarkan tabel 7 di dapatkan data bahwa variabel status reproduksi meliputi umur ibu mempunyai nilai $p$ value 0,000 . Hal ini menunjukkan bahwa status reproduksi meliputi kelompok ibu yang rentang usia reproduksi berisiko ( $<20$ dan $>42$ tahun) dapat juga berisiko mengalami preeklamsia. Faktor usia berpengaruh terhadap terjadinya preeklamsia/eklamsia. Menurut studi di Bangkok, wanita hamil dengan usia $<20$ tahun cenderung mengalami preeklamsia/eklamsia, begitu pula dengan wanita hamil $>35$ tahun. Usia 20 - 30 tahun adalah periode paling aman untuk melahirkan, akan tetapi di negara berkembang sekitar 10\% sampai $20 \%$ bayi dilahirkan dari ibu remaja yang sedikit lebih besar dari anak-anak (Rochjati, 2011). Preeklamsia sering terjadi pada populasi usia lebih dari 35 tahun, menurut Duckitt et al. Hal ini terjadi karena peningkatan reaksi vena yang berperan terhadap faktor yang berkontribusi dalam pengembangan preeklamsia (Kumari, et. al., 2016). Hasil penelitian ini berbeda dengan penelitian Wahyuni, dkk (2015) yang menyatakan bahwa tidak ada hubungan yang signifikan antara umur dengan kejadiaan preeklampsia pada Ibu Hamil di Rumah Sakit Roemani Muhammadiyah Semarang dengan nilai $p$ value 0.768 . Hasil penelitian ini juga berbeda dengan penelitian Fitriani (2009) yang menyatakan bahwa tidak ada hubungan yang bermakna antara umur dengan kejadian preeclampsia di Rumah Sakit Dr. Mohammad Hoesin Palembang, dengan nilai p.value = $0,3>0,05$.

Berdasarkan tabel 7 di dapatkan data bahwa variabel perilaku penggunakan $\mathrm{KB}$ dan pemeriksaan ANC mempunyai nilai $p$ value 0,013 
dan 0,001 ( $p$ value $<0,05)$. Hal ini menunjukkan bahwa perilaku penggunakan $\mathrm{KB}$ dan pemeriksaan ANC beresiko untuk mengalami preeklamsia. Perkiraan kontribusi pelayanan KB terhadap kematian yang disebabkan oleh komplikasi obstetrik lainnya, antara lain eklamsia 20\% (Rozikhan, 2007). Kontrasepsi hormonal berupa pil KB sebagian besar mengandung hormon estrogen dan pregesteron. Hormon dalam kontrsepsi ini telah diatur sedemikian rupa sehingga mendekati kadar hormon dalam tubuh akseptor namun bila digunakan dalam jangka waktu yang lama dapat menimbulkan efek samping. Kedua hormon tersebut memiliki kemampuan untuk mempermudah retensi ion natrium dan sekresi air disertai kenaikan aktivitas rennin plasma dan pembentukan angiontensin sehingga dapat memicu terjadinya peningkatan tekanan darah (Fatmawati, et. al., 2017).

\section{Preeklamsia/eklamsia}

merupakan komplikasi kehamilan berkelanjutan yang dapat dicegah dengan antenatal care. Oleh karena itu melalui antenatal care yang rutin dapat mendeteksi lebih awal adanya tanda dan gejala preeklamsia, oleh karena itu ibu hamil diharapkan dapat secara rutin melakukan pemeriksaan ANC. Sebanyak $90 \%$ kejadian preeklamsia didapatkan pada ibu hamil yang tidak melakukan pemeriksaan antenatal care secara teratur (Rozikhan, 2007). Kebijakan program ANC paling sedikit dilakukan 4 kali selama hamil, yaitu 1 kali pada trimester I, 1 kali pada trimester II, dan 2 kali pada trimester III (Saifuddin, 2012). Pada ibu hamil dengan ANC irreguler 72\% lebih berisiko preeklamsia (RR:1,72 p: 0,055) (Opitasari and Andayasari, 2014).

Berdasarkan tabel 5 di dapatkan data bahwa variabel status reproduksi meliputi paritas mempunyai nilai $p$ value 0,594 ( $p$ value $<0,05$ ). Hal ini menunjukkan bahwa status reproduksi meliputi paritas bukan merupakan faktor penyebab terjadinya preeklamsia. Namun begitu menurut Winkjosastro (2007) ibu yang memiliki paritas $>3$ beresiko mengalami preeklampsia dibandingkan ibu yang memiliki paritas 1-3. Menurut Winkjosastro (2007) pada multi paritas lingkungan endometrium 
Faktor-Faktor Penyebab Kejadian Preeklamsia/Eklamsia Pada Ibu Bersalin Di Ruang Bersalin Rumah Sakit Umum Daerah Panembahan Senopati Bantul

disekitar tempat implantasi kurang sempurna dan tidak siap menerima hasil konsepsi, sehingga pemberian nutrisi dan oksigenisasi kepada hasil konsepsi kurang sempurna dan mengakibatkan pertumbuhan hasil konsepsi akan terganggu sehingga dapat menambah resiko terjadinya preeklampsia. Hasil penelitian ini sama dengan yang dilakukan oleh Wahyuni,dkk. (2015) dan Fauziah (2013) yang menyatakan bahwa tidak ada hubungan yang signifikan antara paritas dengan kejadiaan preeklampsia. Faktor yang mempengaruhi pre-eklampsia frekuensi primigravida lebih tinggi daripada multigravida, terutama primigravida muda. Pada persalinan yang berulang-ulang mempunyai risiko terhadap kehamilan, pada The New England Journal of Medicine tercatat bahwa pada kehamilan pertama risiko terjadi preeklampsia $3,9 \%$, kehamilan kedua $1,7 \%$, dan kehamilan ketiga 1,8\%. Walaupun secara statistik paritas tidak signifikan sebagai faktor penyebab kejadian preeklamsia / eklamsia namun perlu

tetap diharapkan ibu tidak sampai melahirkan berulang-ulang ( $>4$ kali) supaya meminimalkan risiko/komplikasi lain yang dapat terjadi selama periode kehamilan. Berdasarkan tabel 7 di dapatkan data bahwa variable karakteristik responden meliputi pendidikan ibu mempunyai nilai $p$ value 0,000 ( $p$ value $<0,05)$. Hal ini menunjukkan bahwa pendidikan ibu yang kurang, beresiko untuk mengalami preeklamsia. Wanita yang mempunyai pendidikan lebih tinggi akan cenderung lebih memperhatikan kesehatan dirinya daripada yang mempunyai pendidikan lebih rendah. Hasil penelitian Agung Sudpriandono dan Sulchan Sooewan yang disitasi oleh Rozikhan, 2009 menyebutkan bahwa $80(49,7 \%)$ kasus preeklamsia berat mempunyai pendidikan kurang dari 12 tahun, dibanding 72 (44,2\%) kasus bukan preeklamsia berat mempunyai pendidikan lebih dari 12 tahun. 


\section{KESIMPULAN DAN SARAN \\ Kesimpulan}

Faktor penyebab kejadian preeklamsia/eklamsia pada ibu bersalin di Rumah Sakit Umum Daerah Panembahan Senopati adalah status kesehatan meliputi penyakit kronis ( $p$ value 0,000); status reproduksi yang meliputi umur ibu $(p$ value 0,000$)$; perilaku pemeriksanaan antenatal care ( $p$ value 0,001) dan penggunaan $\mathrm{KB}$ ( $p$ value 0,013); karakteristik responden meliputi pendidikan ibu ( $p$ value 0,013). Variabel status kesehatan meliputi riwayat komplikasi dan status reproduksi meliputi paritas tidak memberikan pengaruh secara signifikan terhadap kejadian preeklamsia/eklamsia pada ibu bersalin.

\section{Saran}

$$
\begin{aligned}
& \text { Hasil penelitian ini diharapkan } \\
& \text { dapat memberikan manfaat } \\
& \text { pengetahuan mengenai faktor-faktor } \\
& \text { yang erat hubungan dengan kejadian } \\
& \text { preeklamsia dan eklamsia sehingga } \\
& \text { ibu hamil dengan salah satu faktor } \\
& \text { ataupun lebih dapat mendapatkan } \\
& \text { perhatian sehingga kejadian }
\end{aligned}
$$

preeklamsia dan eklamsia dapat dicegah, ataupun apabila sudah terkena preeklamsia jangan sampai penyakitnya bertambah parah menjadi eklamsia.

\section{DAFTAR PUSTAKA}

Apri, dkk. 2012. Faktor-faktor yang Berhubungan Dengan Terjadinya Preeklamsia-

Anderson \& Schmella. 2017. CE: Preeclampsia: Current Approaches to Nursing Management. Am J Nurs. 117(11): 30-38

Arikunto, S. 2010. Prosedur Penelitian Suatu Pendekatan Praktek. Jakarta: Rineka Cipta.

Dinkes Bantul. 2019. Profil Kesehatan Kabupaten Bantul Tahun 2019 diambil dari https://dinkes.bantulkab.go.id/

Depkes RI. 2012. Profil Kesehatan Indonesia . Diunduh pada tanggal 5 Maret 2018 dari http://www.depkes.go.id/ 
Agnes Mahayanti, Ngatini

Faktor-Faktor Penyebab Kejadian Preeklamsia/Eklamsia Pada Ibu Bersalin Di Ruang Bersalin Rumah Sakit Umum Daerah Panembahan Senopati Bantul

Fadlun. 2012. Asuhan Kebidanan Patologis. Jakarta: Salemba Medika

Fatmawati, L. et al. 2017. Pengaruh Status Kesehatan Ibu terhadapat Derajat

Preeklamsia/eklamsia di Kabupaten Gresik. Dinkes Buletin. 20(2)

Fauziyah,Y. 2013.Obstetri Patologi. Yogyakarta: Nuha Medika

Fitriani, I. 2009. Hubungan Antara Umur dan Paritas Dengan Kejadian Preeklampsia Di Rumah Sakit Dr. Mohammad Hoesin Palembang. Database Jurnal Ilmiah Indonesia Vol. 1 No.2 .

Kumari, VR, Saraswathi, K and Srilaxmi, A. 2016. Oral nifedipine versus intravenous labetalol for control of blood pressure in severe preeclampsia. Journal of Evolution of Medical and Dental Sciences (Vol. 5, Issue 20)
Notoatmodjo, S. 2009. Metodelogi Penelitian Kesehatan. Jakarta : Rineka Cipta.

Notoatmodjo, S. 2010. Ilmu Perilaku Kesehatan. Jakarta : Rineka Cipta.

Opitasari C, Andayasari L. Parity. 2014. Education Level and Risk for ( Pre- ) Eclampsia in Selected

Hospitals in Jakarta. Heal Sci Indones. 5(1):35-9.

Prawirohardjo, S. 2009. Ilmu Kebidanan. Jakarta : Yayasan Bina Pustaka.

Rozikhan. 2007. Faktor - Faktor R isiko Terjadinya Pre-eklampsia Berat di Rumah Sakit Dr. H.

Rochjati, 2011. Skrining Antenatal Pada Ibu Hamil. Surabaya. Airlangga University Press.

Saifuddin. 2012. Ilmu Kebidanan. Jakarta: Yayasan Bina Pustaka Sarwono Prawiroharjdo.

Wahyuni, dkk. 2015. Faktor-faktor yang Berhubungan dengan Kejadian Preeklamsia pada Ibu Hamil di Rumah Sakit Roemani 
Jurnal Keperawatan I CARE, Vol. 2 No. 1 Tahun 2021

Muhammadiyah Semarang. Winkjosastro H.2007. Ilmu Kebidanan.

(http://jurnal.unimus.ac.id/ind Jakarta: YBP-SP

ex.php 